\title{
ПРАВОВАЯ РЕГЛАМЕНТАЦИЯ И ПРИОРИТЕТЫ РАЗВИТИЯ НАЦИОНАЛЬНОГО ЗАКОНОДАТЕЛЬСТВА РЕСПУБЛИКИ КАЗАХСТАН ПО ПРОТИВОДЕЙСТВИЮ НЕГАТИВНЫМ ИНФОРМАЦИОННЫМ ВОЗДЕЙСТВИЯМ НА НЕСОВЕРШЕННОЛЕТНИХ
}

\author{
Хасанова В. В., докторант Казахско-Русского международного университета, г. Актобе, \\ Республика Казахстан
}

DOI: https://doi.org/10.31435/rsglobal_conf/25022021/7419

\begin{abstract}
The article is devoted to the study of the existing legal framework for the protection of minors in the Republic of Kazakhstan from negative impacts in the information sphere, as well as the priority areas of development of national legislation in this area. Today, in the context of globalization, information and communication networks, including the Internet, are an important, and sometimes the only source of information for children. The pandemic of the new coronavirus infection COVID-19 is a confirmation of this, when, against the background of the lack of real communication, children began to spend most of their time on the Internet. Education, leisure, and communication have all moved there. The role of information and communication networks in the life of modern man cannot be overestimated. At the same time, they can be a source of threats and risks to the health, development and mental well-being of children. It is established that the current legislation of the Republic of Kazakhstan contains a number of normative legal acts aimed at ensuring the information protection of minors. However, the system of legal and organizational protection of children in the information sphere is currently at the stage of formation and does not provide a comprehensive response to modern, exponentially growing information challenges and threats. In order to eliminate this gap, it is proposed to develop a unified national strategy for the protection of children in the information environment, with its provisions fixed in the basic document.
\end{abstract}

Keywords: minors; information protection; security, information and telecommunications networks; counteraction.

Введение. Темпы современного технологического развития обязывают выдвигать в разряд приоритетных проблему правового обеспечения информационной безопасности государства, общества и личности (в том числе несовершеннолетней). В такой ситуации наиболее уязвимым в плане воздействия негативной информации на физическое, психическое, нравственное развитие, оказывающей отрицательное влияние на формирование личности, является ребенок, поскольку он находится на пути социализации, не имеет достаточного жененного опыта, нуждается в особой охране и заботе, не всегда способен подвергать получаемую информацию критическому анализу.

Дети каждый день смотрят телевизор часами, но все больше и больше времени они проводят в Интернете, используя навыки, которым они быстро обучаются у своих сверстников. Дети используют интерактивные средства для игры, общения, написания блогов в Интернете, прослушивания музыки, размещения собственных фотографий и поиска других людей для общения в интерактивном режиме. Поскольку существует реальное несоответствие между грамотностью в отношении информационных средств между детьми и взрослыми, большинство взрослых мало знают о том, что делают их дети в Интернете или как они это делают [1]. Интересы человека, которые необходимо охранять в информационном обществе, заключаются прежде всего в реальном обеспечении конституционных прав и свобод человека и гражданина на доступ к открытой информации, на использование информации в интересах осуществления не запрещенной законом деятельности, а также в защите информации, обеспечивает личную безопасность, духовное и интеллектуальное развитие [2].

Проблемами регулирования общественных отношений в информационной сфере и обеспечения безопасности личности (в том числе несовершеннолетней) в информационном пространстве занимались ряд казахстанских ученых, в частности, А.Б. Алханова, P.Е. Джансараева, А.М. Ергали, Ш.Б. Маликова, А.Б. Омарова, С.М. Рахметов и зарубежных, 
среди которых С.А. Буданов, Е.В. Горбачева, Л.Л. Ефимова, С.А. Кочерга, А.И. Савельев, Nicola Haralambous, Barsanti Sam. Reyns, Bradford W., Bonnie S. Taleb, Nassim N. и др.

Целью статьи является анализ норм национального законодательства по вопросам противодействия негативным информационным влияниям на детей и определение направлений развития системы правового регулирование по обеспечению информационной безопасности ребенка в Республике Казахстан.

Поскольку ребенок является особым субъектом общественных отношений, что в соответствии с национальным законодательством и международным правом требует особой защиты со стороны государства. При этом, согласно международными стандартами ребенком признается каждое человеческое существо до достижения 18-летнего возраста, если по закону, применяемому к данному лицу, оно не достигает совершеннолетия раньше [3].

Результаты исследования. Часть 1 ст. 27 Конституции РК гарантирует, что брак и семья, материнство, отцовство и детство находятся под охраной государства. Учитывая изложенное, ребенок как полноценный гражданин РК имеет право быть защищенной от любого негативного влияния, в том числе информационного.

«Мы должны решить вопросы защиты прав детей. Необходимо усилить государственный контроль и найти действенные механизмы для профилактики суицида и буллинга среди детей» сказал Президент Республики Казахстан Касым-Жомарт Токаев в ходе первой сессии Парламента РК седьмого созыва в г. Нур-Султан в январе 2021 года [4]. Ранее о необходимости принятия мер для защиты детей от вредной информации Президент озвучивал на четвертом заседании национального совета общественного доверия. Все это свидетельствует о приоритетности развития данного направления политики государства на современном этапе.

Для достижения указанной цели в Республике Казахстан был принят ряд нормативных актов. Среди которых Закон Республики Казахстан «О правах ребенка в Республике Казахстан» предоставляет каждому ребенку право на свободу слова и выражение своего мнения, свободу совести, развитие своей общественной активности, получение и распространение информации, соответствующей его возрасту [5].

Так, с целью совершенствования правоприменительной практики, методологической базы, нормативно-правового и организационно-технического обеспечения безопасного использования информационно-коммуникационных технологий в национальной системе защиты информации и безопасности автоматизированных систем управления технологическими процессами 30 июня 2017 года Постановлением Правительства Республики Казахстан утверждена Концепция кибербезопасности «Киберщит Казахстана». Одним их направлений данной концепции является обеспечение безопасности личности, общества и государства при применении информационно-коммуникационных технологий [6].

Что касается защиты несовершеннолетнего как самостоятельного субъекта информационных правоотношений, то 30 марта 2020 года Постановлением Правительства Республики Казахстан утверждена «Дорожная карта по усилению защиты прав ребенка, противодействию бытовому насилию и решению вопросов суицидальной среди подростков на 2020-2023 годы». В документе направления деятельности отдельных субъектов по противодействию негативным информационным воздействиям на несовершеннолетних рассмотрен наряду с защитой детей в иных сферах жизни. В соответствии с утвержденным планом предусмотрена реализация комплекса мероприятий по профилактике интернет-зависимости среди молодежи, проведение мониторинга и блокировки отдельных страниц в социальных сетях и Интернете, распространение бесплатного Smart-приложения "Система родительского контроля" для родителей по отслеживанию посещения детьми негативных сайтов и иные мероприятия, направленные на обеспечение защиты детей в информационном пространстве [7].

Важным шагом к развитию и укреплению информационной безопасности несовершеннолетних в Республике Казахстан явилось принятие 2 июля 2018 года Закона «О защите детей от информации, причиняющей вред их здоровью и развитию». Данный документ разработанного в соответствии с модельным законом «О защите детей от информации, наносящей вред их здоровью и развитию», принятым 3 декабря 2009 года межпарламентской ассамблеей государств СНГ, устанавливающим правовые и организационные основы государственной политики и международного сотрудничества государств-участников СНГ в сфере обеспечения информационной безопасности детей $\mathrm{c}$ учетом общепризнанных принципов и норм 
международного права, в том числе закрепленных в Конвенции ООН о правах ребенка и Модельном законе государств-участников СНГ «Об основных гарантиях прав ребенка в государстве».

С принятием Закона Республики Казахстан «О защите детей от информации, причиняющей вред их здоровью и развитию» определение на законодательном уровне получили такие категории как возрастная классификация информационной продукции, информационная продукция для детей, информационная безопасность детей, возрастная категория, знак возрастной категории [8]. Однако считаем, данный Закон нуждается в доработке в части определения перечня видов информации, причиняющей вред здоровью и (или) развитию детей.

Также учитывая, что распространение информации посредством сетей телекоммуникаций носит трансграничный, а зачастую и трансконтинентальный характер, представляется чрезвычайно важным изучение положительного зарубежного и международного опыта противодействия распространению негативной информации с возможностью имплементации отдельных положений в систему национального законодательства. Отметим, что согласно положениям Закона Республики, Казахстан «О национальной безопасности Республики Казахстан» информационная безопасность человека и гражданина относится к сфере национальной безопасности [9].

На сегодняшний день в Республике Казахстан отсутствует единый документ, содержащий программу защиты детей от негативного воздействия на несовершеннолетних информации, содержащейся и получаемой при помощи сетей телекоммуникации.

По нашему мнению, таким документом могла бы стать Стратегия информационной защиты несовершеннолетних (Стратегия), которая должна содержать стратегические цели; этапы реализации; основные правовые принципы; вопросы организационного обеспечения и взаимодействие законодательной и исполнительной власти по противодействию возникающим угрозам. Как отмечают Д.А. Афиногенов и В.В. Воронин «стратегическое планирование позволяет на практике реализовывать «принцип взаимосвязи и взаимозависимости задач обеспечения национальной безопасности с динамичным социально-экономическим развитием государства» $[10$, с.14].

Целью Стратегии является обеспечение прав и свобод ребенка, его защита от любых форм насилия и эксплуатации в информационной (цифровой) среде. Она должна быть направлена на формирование политики государства, а также последовательной ее реализации, с вовлечением общественности, гражданского общества, научных организаций и более широких кругов населения, а положения базироваться на принципах верховенства основополагающих прав и свобод человека и гражданина, определенных Конституцией Республики Казахстан и нормами международного права; согласование права ребенка на защиту в информационной среде с другими правами; гендерного равенства; беспристрастного отношения и недопущении дискриминации; международного сотрудничества; системности; партнерства и поддержки; обеспечение участия детей в формировании и реализации политики по безопасному использованию цифровой среды.

В целях качественного обеспечения информационной защиты несовершеннолетних предлагается предусмотреть:

- проведение виктимологической профилактики путем внедрения в образовательные программы средних и средне-специальных учебных заведений материалов, обучающих несовершеннолетних медиаграмотности, базовым навыкам информационной безопасности с учетом возрастных особенностей и отдельно для детей с особыми потребностями (инвалидностью, страдающими психическими заболеваниями и т.д.) и повышающие уровень медиакультуры;

- при преподавании дисциплины «Основы информатики» в средних и среднеспециальных учебных заведениях привлечение для проведения занятий практических работников-специалистов в области информационной безопасности для обучения компьютерной грамотности и навыкам распознавания потенциально возможных вызовов и угроз (насилие, жестокость, вовлечение в противоправную деятельность и т.д.) в цифровой сфере, а также правилам поведения в такой ситуации;

- модернизацию работы педагогов и школьных психологов по определению моральнопсихологического состояния несовершеннолетних посредством регулярного проведения опросов, анкетирования, бесед и анализа полученных данных в целях выявления потенциальных угроз информационной безопасности обучающихся, их направленность и формирование психологического иммунитета от негативного информационного воздействия; 
- внедрение системы «родительский контроль» во всех реализуемых на территории Республики Казахстана аудио, видео устройствах;

- устранение цифрового неравенства среди детей независимо от социального статуса и места проживания;

- объединение усилий государства, общественных объединений, научных учреждений, медиа по эффективному противодействию информационным угрозам, пропаганда правопослушного поведения, патриотизма среди молодежи посредством сетей телекоммуникаций

- обеспечение безопасного использования Интернета с внедрением согласия родителей (законных представителей) на сбор и обработку персональных данных несовершеннолетних и систему подтверждения возраста при совершении интернет-покупок детей младше 16 лет;

- подготовка специально обученных кадров по расследованию уголовных правонарушений, посягающих на информационную безопасность детей, а также специалистов по реабилитации детей-жертв информационных преступлений;

- создание единой службы поддержки детей, пострадавших от противоправных действий (буллинг, вовлечение в «группы смерти», посягательства на половую неприкосновенность и т.п.) совершенных посредством сетей телекоммуникаций, в том числе сети Интернет, для оказания консультативной, психологической, медицинской, юридической помощи.

Важно отразить приоритетность превентивных мер в системе противодействия информационным угрозам, где важная роль отводится родителям (законным представителям) и педагогам. Исходя из специфики детского возраста, следует сказать, что в профилактической работе с такой группой большое значение имеют, прежде всего, меры не правового характера, а педагогические психологические, медицинские [11, с. 69].

Согласимся с мнением А.Ю. Юрченко, который приводит перечень главных общих мероприятий, которые должны осуществить родители и педагоги для снижения уровня виктимности детей и в обычной жизни, и социальных сетях: уход за нормальным развитием ребенка с целью раннего выявления психических или физических пороков; правильное общее и половое воспитание, формирование культуры общения; привитие ребенку навыков поведения в нестандартных, в том числе виктимогенних ситуациях; закладка основ правовых знаний, которые через средства массовой информации и другим способом должны приходиться разными специалистами-юристами, психологами, педагогами; разъяснение родителям, что их поведение является главным образцом и авторитетом для ребенка и лучшая профилактика - это их личный пример правильного поведения. [12, с.337]. Степень правового вмешательства и строгость ответственности должны определяться с учетом возрастной классификации детей и уровня информационных рисков.

Положительным можно признать опыт Соединенных Штатов Америки и Израиля, где в структуре правоохранительных органов созданы специальные подразделения для борьбы с информационными правонарушениями, и рядовые сотрудники имеют компетенции для правильного реагирования на подобные сообщения [13].

Успех реализации положений Стратегии на практике будет измеряться в достижении следующих результатов: минимизация фактов нарушения основных прав и свобод ребенка; возможность прогнозирования возможных рисков, их направленности; владение работниками правоохранительных и судебных органов достаточными компетенциями и средствами для оперативного реагирования на факты нарушения прав ребенка в цифровой среде; создание системы психологической поддержки несовершеннолетних жертв в сфере телекоммуникаций; поддержание должного уровня защиты детей от вредной информации в соответствии в современными информационными вызовами и угрозами; повышение уровня медиаграмотности несовершеннолетних с учетом возрастных особенностей и взрослых лиц в целях обеспечения надлежащего контроля при общении детей через информационно-телекоммуникационные сети; усиление родительского и педагогического участия в контроле за распространением вредной информации и вовлечение в данную деятельность общественные организации и независимые институты.

Выводы. Подводя итог, следует отметить, что сегодня в обществе назрела объективная необходимость правового противодействия негативному воздействию информации на детей. В настоящее время сфера информационно-коммуникативных отношений, подлежащая правовому регулированию весьма обширна. В первую очередь это связано с получением, обменом, распространением информации по сетям телекоммуникации, в том числе всемирной сети 
Интернет, зачастую позволяющей сохранять анонимность и обеспечивающих безграничную свободу действий. Ряд существующих нормативных правовых актов Республики Казахстан содержат отдельные аспекты обеспечения информационной защиты несовершеннолетних. Закон Республики Казахстан «О защите детей от информации», направленный на защиту детей от информации, причиняющей вред их здоровью и развитию, отражает гарантии информационной безопасности, однако и он нуждается в доработке. Стремительные темпы развития информационно-коммуникационных технологий порождают новейшие глобальные информационные угрозы, что несомненно необходимо учитывать при выработке механизмов противодействия негативному информационному воздействию. В этой связи необходимо предусмотреть единый документ стратегического характера каким могла бы стать Стратегия информационной защиты несовершеннолетних в Республике Казахстан к духовному и культурному развитию детей.

\section{ЛИТЕРАТУРА}

1. Retrieved from http://eycb.coe.int/compasito/ru/chapter_5/9.html (дата обращения 01.02.2021 г.)

2. Retrieved from https://www.sgu.ru/sites/default/files/conf/files/2015/10/eroshenko_a.v._g._ryazan_informacionn aya_bezopasnost_lichnosti_v_kommunikacionnom_processe.doc (дата обращения 09.02.2021 г.)

3. Конвенция о правах ребенка. Принята резолюцией 44/25 Генеральной Ассамблеи от 20 ноября 1989 года. Retrieved from https://www.un.org/ru/documents/decl_conv/conventions/childcon.shtml (дата обращения 09.02.2021 г.)

4. Retrieved from https://www.inform.kz/ru/kasym-zhomart-tokaev-vyskazalsya-o-profilaktike-suicida-ibullinga-sredi-detey_a3741436

5. Закон Республики Казахстан от 8 августа 2002 года №345-II «O правах ребенка в Республике Казахстан». Retrieved from https://online.zakon.kz/document/?doc_id=1032460 (дата обращения 09.02.2021 г.)

6. Постановление Правительства Республики Казахстан от 30 июня 2017 года №407 «Об утверждении Концепции кибербезопасности («Киберщит Казахстана»)» Retrieved from https://online.zakon.kz/Document/?doc_id=39754354 (дата обращения 09.02.2021 г.)

7. Постановление Правительства Республики Казахстан от 30 марта 2020 года № 156 «Об утверждении Дорожной карты по усилению защиты прав ребенка, противодействию бытовому насилию и решению вопросов суицидальности среди подростков на 2020 - 2023 годы». Retrieved from http://adilet.zan.kz/rus/docs/P2000000156 (дата обращения 09.02.2021 г.)

8. Закон Республики Казахстан от 2 июля 2018 года №169-VI «О защите детей от информации, причиняющей вред их здоровью и развитию» Retrieved from https://online.zakon.kz/document/?doc_id=39797352 (дата обращения 09.02.2021 г.)

9. Закон Республики Казахстан от 6 января 2012 года №527-IV «O национальной безопасности Республики Казахстан». Retrieved from https://online.zakon.kz/document/?doc_id=31106860 (дата обращения 09.02.2021 г.)

10. Д.А. Афиногенов, В.В. Воронин. Роль документов стратегического планирования: правовые аспекты // Государственная власть и местное самоуправление. 2014. № 2. С. 13-17.

11. Веселуха В. значение виктимологической профилактики в системе предотвращения преступлений / В. Веселуха / Право Украины. - 1999. - № 10. - С. 67-73.

12. А. Ю. Юрченко Проблемы безопасности детей в социальных сетях и Интернете (виктимологический аспект) / А. Ю. Юрченко // Сравнительно-аналитическое право: электрон. профессиональное наук. издание. - 2013. - № 3-1. - С. 336-338.

13. Patchin J. Law Enforcement Perspectives on Cyberbullying. (2011). Retrieved from http://cyberbullying.us/blog/law-enforcement-perspectives-on-cyberbullying.html. 